\title{
Biodegradation of urea- $\mathrm{NH}_{3}$ treated wheat straw using anaerobic rumen fungi
}

\author{
T.L. Dayananda ${ }^{1}$, R. Nagpal ${ }^{1}$, A.K. Puniya ${ }^{1}$, J.P. Sehgal ${ }^{2}$ \\ and K. Singh ${ }^{1,3}$
}

\author{
National Dairy Research Institute, \\ ${ }^{1}$ Dairy Microbiology Division, \\ ${ }^{2}$ Dairy Cattle Nutrition Division \\ Karnal-132 001, India
}

(Received 2 February 2007; revised version 24 April 2007; accepted 6 September 2007)

\begin{abstract}
In present study, the in vitro dry matter digestibility and cell-wall content degradation of urea$\mathrm{NH}_{3}$ treated wheat straws were reported by incubating with rumen liquor and anaerobic fungi i.e. Orpinomyces sp. C-14 or Piromyces sp. WNG-12. The maximum digestibility of dry matter $(55.8 \%)$ in urea- $\mathrm{NH}_{3}$ treated wheat straws was shown by Piromyces sp. WNG-12, when compared to Orpinomyces sp. C-14 (54.3\%) and control (45.5\%) after $72 \mathrm{~h}$. The cell-wall contents in terms of percent neutral detergent fibre, acid detergent fibre and acid detergent lignin were found to decrease significantly when wheat straw was treated with Piromyces sp. WNG-12, followed by Orpinomyces sp. C-14 and controls, for 48 or $72 \mathrm{~h}$.
\end{abstract}

KEY WORDS: anaerobic fungi, wheat straw, biodegradation, urea- $\mathrm{NH}_{3}$ treatment

\section{INTRODUCTION}

Cereal straws, that are available in large quantities for ruminants feeding, are poor in nutritional quality because of low protein and high lignin contents in these feeds. Yet, these straws are the potential source of cell-wall polysaccharides such as cellulose and hemicellulose. However, lignin prevents a close contact between the polysaccharides and rumen microorganisms. Therefore, upgrading of straw

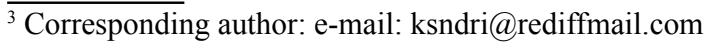


quality through chemical and/or biological treatments is an important strategy for improving the livestock productivity. In these directions, urea- $\mathrm{NH}_{3}$ treatment received a major attention as an appropriate technology for chemical treatment of straws (Rai and Gupta, 1990; Flachowsky et al., 1996; Dayal et al., 2002). During treatment of straws with urea, $\mathrm{NH}_{3}$ is released to form $\mathrm{NH}_{4} \mathrm{OH}$ that improves the nutritive value of cereal straws by degrading lignin (Sehgal and Patnayak, 1993; Prakash et al., 2004). Similarly, anaerobic rumen fungi are also known for their ability to attack, penetrate and utilize all categories of recalcitrant plant biomass (Orpin, 1977). The ruminal fungi have been shown to degrade the cereal straws to a significant extent under in vitro, i.e. $34.4 \%$ (Thareja et al., 2006) and in vivo conditions, i.e. 59.95 (Dey et al., 2004) and 41.8\% (Lee et al., 2000). However, scientific evidences are not known on the biodegradation of urea- $\mathrm{NH}_{3}$ treated wheat straw using ruminal anaerobic fungi so as to get the double benefits of chemical and biological treatments. Hence, in this study, an effort was made to undertake the degradation of urea- $\mathrm{NH}_{3}$ treated wheat straw using rumen fungi to study the further enhancement in the digestible energy of straws, in order to prepare a good quality animal feed.

\section{MATERIAL AND METHODS}

\section{Substrate}

Wheat straw particles $(100 \mathrm{~g})$, grounded to mesh size of $0.5 \mathrm{~mm}$, were taken into polypropylene bags $(25 \times 17 \mathrm{~cm})$ and mixed with $4 \%$ urea $(40 \%$ moisture). The bags were sealed and stored for 30 days at ambient temperature $\left(28-32^{\circ} \mathrm{C}\right)$ and used as urea- $\mathrm{NH}_{3}$ treated wheat straw substrate for further biological treatments and degradation analyses (Singh et al., 1989).

\section{Rumen fungal isolates}

Rumen fungi (Orpinomyces sp. C-14 and Piromyces sp. WNG-12) were procured from Fungal Biotechnology Laboratory, Dairy Microbiology Division, NDRI, Karnal, and tested morphologically on the basis of number of flagella per zoospore, thallus morphology (monocentric or polycentric), and rhizoid type (filamentous or a vegetative cell) to check the purity of the cultures before being used as inoculums (Thareja et al., 2006; Tripathi et al., 2007). The fungal cultures were grown and maintained as per the modified Hungate's roll-tube technique (Joblin, 1981). The roll-tubes were kept in $\mathrm{CO}_{2}$ incubator at $39 \pm 1{ }^{\circ} \mathrm{C}$ and the colonies were sub-cultured routinely in Joblin's broth supplemented with antibacterial antibiotics (penicillin and streptomycin). 
In vitro degradation experiments

In vitro dry matter digestibility (IVDMD) trials were conducted in $100 \mathrm{ml}$ wide mouthed conical flasks capped with rubber cork containing two inlets fitted with glass tubes and incubated at $39 \pm 1{ }^{\circ} \mathrm{C}$ for 48 to $72 \mathrm{~h}$ (AOAC, 1995). The four different treatments designated as $\mathrm{T}_{1}$ to $\mathrm{T}_{4}$ in triplicates were made as follows:

$\mathrm{T}_{1}$ : untreated wheat straw $+40 \mathrm{ml} \mathrm{McDoughall's} \mathrm{buffer}+10 \mathrm{ml}$ strained rumen liquor (SRL) $+5 \mathrm{ml}$ cell-free anaerobic broth;

$\mathrm{T}_{2}$ : urea- $\mathrm{NH}_{3}$ treated wheat straw $+40 \mathrm{ml}$ McDoughall's buffer $+10 \mathrm{ml} \mathrm{SRL}$

$+5 \mathrm{ml}$ cell-free anaerobic broth;

$\mathrm{T}_{3}$ : urea- $\mathrm{NH}_{3}$ treated wheat straw $+40 \mathrm{ml} \mathrm{McDoughall's} \mathrm{buffer}+10 \mathrm{ml}$ SRL

$+5 \mathrm{ml}$ of Orpinomyces C-14 culture $\left(\approx 10^{6} \mathrm{cfu} / \mathrm{ml}\right)$;

$\mathrm{T}_{4}$ : urea- $\mathrm{NH}_{3}$ treated wheat straw $+40 \mathrm{ml} \mathrm{McDoughall's} \mathrm{buffer}+10 \mathrm{ml} \mathrm{SRL}$

$+5 \mathrm{ml}$ of Piromyces WNG-12 culture broth $\left(\approx 10^{6} \mathrm{cfu} / \mathrm{ml}\right)$.

For this, fresh rumen liquor was collected before feeding from the rumen of permanently fistulated crossbred male calf (Sahiwal $\times$ Holstein-Friesian; age $\approx$ $3 \mathrm{yr}$; average weight $\approx 250 \mathrm{~kg}$ ) fed on a standard diet containing wheat straw, green fodder maize and concentrate mixture (\%: groundnut cake 40 , maize 20 , barley 20 , wheat bran 17 , mineral mixture 2 , salt, 1) to meet their nutritional requirements (NRC, 2001). Rumen liquor was strained through four layers of muslin cloth and clarified by centrifugation at $16,000 \mathrm{~g}$ for $20 \mathrm{~min}$ before being added to the medium. All the flasks were flushed thoroughly with $\mathrm{CO}_{2}$ and then placed in incubator at $39 \pm 1{ }^{\circ} \mathrm{C}$ for 48 and $72 \mathrm{~h}$. After incubation, samples from each trial were centrifuged at $2800 \mathrm{~g}$ for $10 \mathrm{~min}$. The pellets were dried at $100^{\circ} \mathrm{C}$ for $24 \mathrm{~h}$ and analysed for percent IVDMD (Tilley and Terry, 1963), neutral detergent fibre (NDF), acid detergent fibre (ADF) and acid detergent lignin (ADL) contents (VanSoest et al., 1991). Data were recorded as mean \pm S.D. of three independent replicates and were statistically analysed using ANOVA after suitable transformation, and standard deviation was calculated by the method of Snedecor and Cochran (1980).

\section{RESULTS}

Figure 1 depicts that among the four different chemical and biological treatments given to wheat straw, the IVDMD of treated straw was maximum (55.8\%) after $72 \mathrm{~h}$ in treatment $\mathrm{T}_{4}$ i.e. Piromyces sp. WNG-12, followed by other treatments in the order of $\mathrm{T}_{3}(54.3 \%), \mathrm{T}_{2}(45.5 \%)$ and $\mathrm{T}_{1}(38.8 \%)$ irrespective of the period of incubation. Similar to IVDMD, there was also maximum reduction of NDF contents in treatment $T_{4}$ when compared with $T_{1}$ after $72 \mathrm{~h}$. The NDF contents in all the treatments were found to decrease with increased incubation periods from 
48 to $72 \mathrm{~h}$. The percent decrease in ADF contents were more in treatments $\mathrm{T}_{2}$, $\mathrm{T}_{3}$ and $\mathrm{T}_{4}$, in the increasing order when compared to treatment $\mathrm{T}_{1}$. Following the pattern of NDF and ADF, the ADL contents in treatment $T_{2}$ differed significantly with other treatments, i.e. $\mathrm{T}_{1}, \mathrm{~T}_{3}$ and $\mathrm{T}_{4}$. The percent decrease in $\mathrm{ADL}$ was highest after $72 \mathrm{~h}$ in treatment $\mathrm{T}_{4}$ when compared to any other treatment including control (Figure 1).
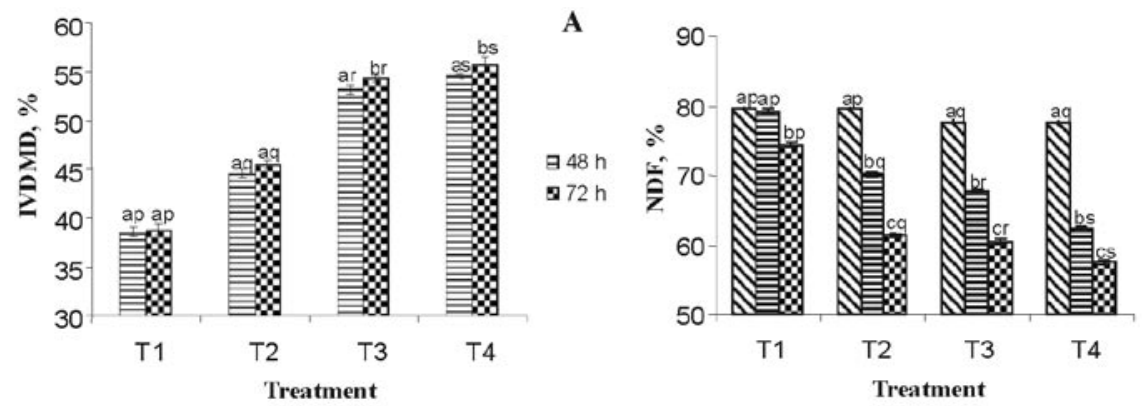

B
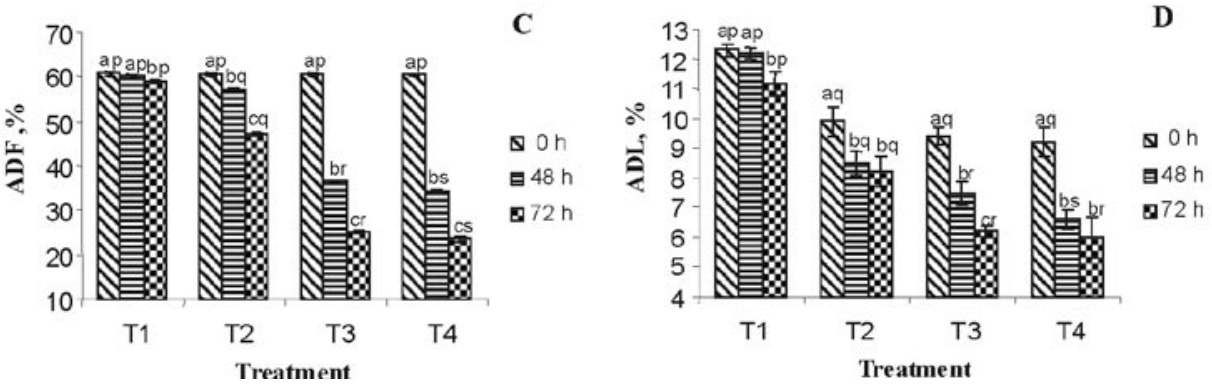

Figure 1. Effect of rumen fungi on IVDMD and cell-wall contents of urea- $\mathrm{NH}_{3}$ and untreated wheat straw $\left(\mathrm{T}_{1}\right.$ : untreated wheat straw $+40 \mathrm{ml}$ McDoughall's buffer $+10 \mathrm{ml}$ strained rumen liquor (SRL) $+5 \mathrm{ml}$ cell-free anaerobic broth; $\mathrm{T}_{2}:$ urea- $\mathrm{NH}_{3}$ treated wheat straw $+40 \mathrm{ml} \mathrm{McDoughall's} \mathrm{buffer} \mathrm{+}$ $10 \mathrm{ml} \mathrm{SRL}+5 \mathrm{ml}$ cell-free anaerobic broth; $\mathrm{T}_{3}$ : urea- $\mathrm{NH}_{3}$ treated wheat straw $+40 \mathrm{ml} \mathrm{McDoughall's}$ buffer $+10 \mathrm{ml} \mathrm{SRL}+5 \mathrm{ml}$ of Orpinomyces $\mathrm{C}-14$ culture; $\mathrm{T}_{4}$ : urea- $\mathrm{NH}_{3}$ treated wheat straw $+40 \mathrm{ml}$ McDoughall's buffer $+10 \mathrm{ml} \mathrm{SRL}+5 \mathrm{ml}$ of Piromyces WNG-12 culture broth). Error bars indicate the standard deviation of the mean $(n=3)$. Mean bars with different letters $(a-c)$ in same treatment at different incubation periods differ significantly $(\mathrm{P}<0.05)$. Mean bars with different letters $(\mathrm{p}-\mathrm{s})$ at same incubation period in different treatments differ significantly $(\mathrm{P}<0.05)$

\section{DISCUSSION}

The maximum dry matter digestibility shown by treatment $\mathrm{T}_{4}$ might be due to the greater hydrolytic activity of Piromyces sp. WNG-12, as reported earlier by Thareja et al. (2006) and Tripathi et al. (2007). Anaerobic fungi can break 
the ester linkages that connect lignin to hemicellulose by producing feruloyl and p-coumaroyl esterases (Borneman et al., 1990), ultimately increasing the digestibility of lignified plant fibres. Dey et al. (2004) also reported similar results for increase in digestibility of wheat straw with the oral administration of Orpinomyces sp. C-14 in growing male cross-bred calves. The increase in digestibility in treatment $\mathrm{T}_{2}$, when compared with $\mathrm{T}_{1}$, might be due to the loosened lignocellulolytic bonds after urea- $\mathrm{NH}_{3}$ treatment of wheat straw. The similar results of increase in digestibility of straws after urea- $\mathrm{NH}_{3}$ treatment were obtained by other workers (Singh et al., 1989; Kumar and Singh, 1990). Maximum reduction of NDF and ADF contents in treatment $\mathrm{T}_{4}$ when compared with $\mathrm{T}_{1}$ might also be due to the maximum hydrolytic activity of Piromyces sp. WNG-12. The difference between treatment $\mathrm{T}_{1}$ and $\mathrm{T}_{2}$ indicates that the urea- $\mathrm{NH}_{3}$ treatment improved the digestibility of wheat straw, as also reported by Rai and Gupta (1990). However, higher degradation in $\mathrm{T}_{3}$ and $\mathrm{T}_{4}$ indicated that hydrolytic enzymes produced by respective fungal culture further acted upon, loosened bonds and digested the cellwall constituents of wheat straw. The results of NDF disappearance after anaerobic fungal incubation are well in agreement with that of Singh et al. (1989), Dey et al. (2004), Manikumar et al. (2004) and Thareja et al. (2006). Ruminal anaerobic fungi are also efficient degraders of lignin and it further assists in digestion of plant cell-wall by ruminal bacteria (Ushida et al., 1997). The ADL content in treatment $\mathrm{T}_{2}$ differed significantly with $\mathrm{T}_{1}$, certainly because of the pre-treatment of wheat straw with urea for 30 days that led to solublization of ADL. The treatments $\mathrm{T}_{3}$ and $\mathrm{T}_{4}$ also differed significantly with each other indicating the varying degree of lignolytic activities shown by the two different fungal isolates. The results of ADL reduction are also well in agreement with the work of other researchers (Dey et al., 2004; Manikumar et al., 2004), who reported a decrease in ADL contents of wheat straw after fungal treatments.

\section{CONCLUSIONS}

Based on overall results obtained, it could be concluded that Piromyces sp. WNG-12 is more effective in enhancing the in vitro digestibility of urea- $\mathrm{NH}_{3}$ treated wheat straw when compared with Orpinomyces sp. C-14 and control. Hence, this strain could be exploited in future for administration in ruminants after making some feeding trials to authenticate the reproducibility of results under in vivo conditions. 


\section{REFERENCES}

AOAC, 1995. Association of Official Analytical Chemists, Official Methods of Analysis. $16^{\text {th }}$ Edition. Arlington, VA

Borneman W.S., Hartley R.D., Morrison W.H., Akin D.E., Ljungdahl L.G., 1990. Feruloyl and $p$-coumaroyl esterase from anaerobic fungi in relation to plant cell-wall degradation. Appl. Microbiol. Biotechnol. 33, 345-351

Dayal J.S., Krishna N., Rao E.R., Reddy T.J., 2002. Evaluation of urea-NH $\mathrm{NH}_{3}$ treated palm press fibre by in vitro, in sacco and in vivo techniques. Indian J. Anim. Nutr. 19, 293-300

Dey A., Sehgal J.P., Puniya A.K., Singh K., 2004. Influence of an anaerobic fungal cultures (Orpinomyces sp.) administration on growth rate, ruminal fermentation and nutrient digestion in calves. Asian-Austr. J. Anim. Sci. 17, 820-824

Flachowsky G., Ochrimenko W.I., Schneider M., Richter G., 1996. Evaluation of straw treatment with ammonia sources on growing bulls. Anim. Feed Sci. Tech. 60, 117-130

Joblin K.N., 1981. Isolation, enumeration and maintenance of rumen anaerobic fungi in roll tubes. Appl. Environ. Microbiol. 42, 1119-1122

Kumar N., Singh K., 1990. Chemical and microbiological changes during solid substrate fermentation of wheat straw with Coprinus fimetarius. Biol. Wastes 33, 231-142

Lee S.S., Ha J.K., Cheng K.J., 2000. Influence of an anaerobic fungal culture administration on in vivo ruminal fermentation and nutrient digestion. Anim. Feed Sci. Tech. 88, 201-217

Manikumar B., Puniya A.K., Singh K., Sehgal J.P., 2004. In vitro degradation of cell-wall and digestibility of cereal straws treated with anaerobic ruminal fungi. Indian J. Exp. Biol. 42, 636-638.

NRC, 2001. Nutrient Requirements of Dairy Cattle. $7^{\text {th }}$ Edition. National Academy of Sciences. Washington, DC

Orpin C.G., 1977. The rumen flagellate Piromonas communis: Its life history and invasion of plant material in the rumen. J. Gen. Microbiol. 99, 107-117

Prakash B., Shivaiah K., Reddy Y.R., Krishna N., 2004. Evaluation of urea-treated maize stover based complete feed in goats. Indian J. Anim. Nutr. 21, 77-80

Rai S.N., Gupta B.N., 1990. Effect of long-term feeding of urea (ammonia) treated wheat straw on intake, nutrient utilization, nitrogen metabolism and economics of feed last in yearling Murrah buffalo. Buffalo J. 1, 49-62

Sehgal J.P., Patnayak B.C., 1993. Utilization of urea- $\mathrm{NH}_{3}$ treated Cenchrus ciliaris grass hay by sheep. J. Livest. Poultry Prod. 9, 22-26

Singh K., Rai S.N., Singh G.P., Gupta B.N., 1989. Solid state fermentation of urea-ammonia treated wheat and rice straws with Coprinus fimetarius. Indian J. Microbiol. 29, 371-376

Snedecor G.W., Cochran W.G., 1980. Statistical Methods. $7^{\text {th }}$ Edition. The Iowa State University Press, Iowa (USA)

Thareja A., Puniya A.K., Goel G., Nagpal R., Jehgal J.P., Singh P.K., Singh K., 2006. In-vitro degradation of wheat straw by anaerobic fungi from small ruminants. Arch. Anim. Nutr. 60, 412-417

Tilley J.M.A., Terry R.A., 1963. A two-stage technique for the in vitro digestion of forage crops. J. Brit. Grassl. Soc. 18, 104-111

Tripathi V.K., Sehgal J.P., Puniya A.K., Singh K., 2007. Hydrolytic activities of anaerobic fungi from wild blue bull (Boselaphus tragocamelus). Anaerobe 13, 36-39

Ushida K., Matsui H., Fujino Y., Ha J.K., 1997. Role and potential of ruminal fungi in fibre digestion. Asian-Austr. J. Anim. Sci. 10, 541-550

Van Soest P.J., Robertson J.B., Lewis B.A., 1991. Methods for dietary fiber, neutral detergent fiber and non-starch polysaccharide in relation to animal nutrition. J. Dairy Sci. 74, 3584-3597 